УДК 331.108

https://doi.org/10.52058/2708-7530-2021-9(15)-346-357

Стовба Тетяна Анатоліївна кандидат економічних наук, доцент кафедри економіки та морського права, Херсонська державна морська академія, пр. Ушакова, 20, м. Херсон, 73000, тел.: (0552) 49-59-02, e-mail: stovba.t1210@gmail.com, https://orcid.org/0000-0003-2433-1122

\title{
РОЗВИТОК ЛЮДСЬКОГО КАПТАЛУ: ВИКЛИКИ ТА МОЖЛИВОСТІ ДЛЯ ЗАКЛАДІВ ВИЩОЇ ОСВІТИ
}

Анотація. Досліджено світові тенденції щодо людського капіталу та можливості його розвитку вітчизняними закладами вищої освіти. Проаналізовано втрати бізнесу від наявної кваліфікаційної ями в світі. Визначені виклики, які виникають внаслідок дисбалансу потреб бізнесу і можливостей ринку праці та співробітників. Обгрунтовано, що у сучасному світі зростатиме попит на офлайнкурси підвищення кваліфікації та перепідготовки, масові відкриті онлайн-курси, марафони, тренінги, менторство фахівців певної галузі.

Доведено, що світ формує нові запити щодо якості компетентностей працівників, але освітній системі потрібен час, щоб перейти від системи освіти, основи якої закладено в епоху Індустрії 2.0 до нових запитів, характерних Індустрії 4.0, яка передбачає формування масової персоналізації освіти.

На основі проведеного аналізу з метою адаптації закладів вищої освіти під потреби кожної людини запропоновано впроваджувати масову персоналізацію освіти шляхом формування індивідуальних освітніх траєкторій, тьюторинг, формування культури постійного розвитку та освіти впродовж життя, розвиток дистанційної освіти, створення бренду закладу вищої освіти та особистого бренду викладача.

Розглянуто можливості реалізації напрямків розвитку людського капіталу на прикладі Херсонської державної морської академії. Запропоновані напрямки формування унікального треку розвитку здобувача, що сприятиме вирішенню проблеми кваліфікаційної ями пропонуючи курсанту замість однакової освіти цікавий саме йому шлях.

Обгрунтовано, що застосування тьюторингу дозволить виховати особистостей, здатних до свідомого вибору власного життєвого шляху, відповідальних за себе, близьких, суспільство в цілому, толерантних, ініціативних, із стійкою громадянською позицією.

Визначені переваги дистанційної освіти, яка дозволить кожній людині навчатися протягом всього життя. Формуванню бренду сприятиме створення цифрового золота закладу, що дозволить зробити прозорим та зручним процес освітньої діяльності, впровадити сильну корпоративну культуру, створити 
особистий бренд викладача. Розглянуто переваги та напрямки створення особистого бренду викладача.

Ключові слова: людський капітал, кваліфікаційна яма, розвиток людського капіталу, індивідуальні освітні траєкторії, тьюторинг, дистанційна освіта, бренд закладу вищої освіти, особистий бренд викладача.

Stovba Tetyana Anatoliyivna Candidate of Economic Sciences, associate professor of Economics and Maritime Law Department, Kherson State Maritime Academy, Ushakov Ave., 20, Kherson, 73000, tel.: (0552) 49-59-02 e-mail: stovba.t1210@gmail.com, https://orcid.org/0000-0003-2433-1122

\title{
HUMAN CAPITAL DEVELOPMENT: CHALLENGES AND OPPORTUNITIES FOR HIGHER EDUCATION INSTITUTIONS
}

\begin{abstract}
Global trends in human capital and opportunities for its development by domestic higher education institutions are studied. The losses of business from the existing qualification pit in the world are analyzed. The challenges that arise due to the imbalance of business needs and opportunities of the labor market and employees are identified. It is substantiated that in the modern world the demand for offline refresher and retraining courses, mass open online courses, short-term practical trainings, mentoring of specialists in a certain field will grow.

It is proven that the world is forming new demands on the quality of workers' competencies, but the education system needs time to move from the education system, which is based on the era of Industry 2.0 (requirements for workers from large-scale industrial production: standardized knowledge and skills, ability to discipline lifelong action) to the new demands of Industry 4.0, which involves the formation of mass personalization of education.
\end{abstract}

Based on the analysis to adapt higher education institutions to the needs of each person, it is proposed to introduce mass personalization of education through the formation of individual educational trajectories, tutoring, culture of continuous development and lifelong learning, distance education, higher education brand and teacher's personal brand.

Possibilities of realization of human capital development directions an example of the Kherson state maritime academy are considered. The directions of development a unique track formation of the applicant which will promote the decision of a qualifying pit offering problem to the cadet instead of identical education the way interesting to it are offered.

It is substantiated that the use of tutoring will educate individuals who are able to consciously choose their own way of life, responsible for themselves, loved ones, society as a whole, tolerant and proactive, with a stable civic position.

The advantages of distance education, which will allow everyone to learn throughout life, have been identified. The formation of the brand will be facilitated by 
the creation of digital gold of the institution, which will make the process of educational activity transparent and convenient, introduce a strong corporate culture and create a personal brand of the teacher. The advantages and directions of creating a personal brand of a teacher are considered.

Keywords: human capital, qualification pit, human capital development, individual educational trajectories, tutoring, distance education, brand of higher education institution, personal brand of the teacher.

Постановка проблеми. Швидкість розвитку технологій у світі передбачає необхідність відповідного реагування та пристосування до змін працівників. Кожна країна приділяє значну увагу впровадженню сучасних технологій, зокрема тих, що притаманні Індустрії 4.0, яка передбачає повну цифровізацію усіх сфер людського життя, об’єднання у глобальну промислову мережу речей та послуг [1, c. 24]. Україна долучилась до цього процесу - розроблено «Національну стратегію Індустрії 4.0». Темпи переходу від одного стану розвитку до іншого залежать від ступеня готовності людей впроваджувати ці зміни.

У світі спостерігається зростання впливу людського капіталу на приріст національного багатства. Частка людського капіталу у світовому національному багатстві дорівнює 64\%, природного капіталу - 20\%, фізичного становить лише 16\% [2]. Питома вага людського капіталу у національному багатстві розвинених країн - Фінляндія, Швейцарія, Німеччина, Японія, США - складає до $80 \%$ [2]. Основний приріст національного багатства визначається наявним людським капіталом та умовами, створеними для його розвитку. Однією із найважливіших умов такого приросту, безперечно, виступає освіта, яка має стати драйвером розвитку країни. Проте існуюча система освіти не гармонізована 3 ринком праці, не має довгострокових прогнозів щодо того, які компетентності та професії будуть затребувані через 20-30 років.

Аналіз останніх досліджень і публікацій. Розвитку людського капіталу присвячені дослідження Т. Шульца [3], Г. Беккера [4], О. Грішнової [5], О. Захарової [6], та ін., які приділяли багато уваги дослідженню сутності категорії, ії складовим елементам, концепціям розвитку, принципам інвестування у людський капітал тощо. Звісно, всі дослідження свідчать про необхідність формування та розвитку людського капіталу. Наразі актуальними постають питання щодо можливостей впливу закладів вищої освіти на формування та розвиток людського капіталу в умовах цифровізації. Дослідження доводять, що наразі від 5\% до 45\% населення різних країн вже працюють у гіг-економіці, а третина видів зайнятості до 2035 року зміниться через цифровізацію [7, с. 11].

Метою статті $є$ дослідження світових трендів щодо людського капіталу та можливостей його розвитку вітчизняними закладами вищої освіти (ЗВО) в умовах цифровізації.

Виклад основного матеріалу. Глобальні тренди породжують нові можливості для трансформації індустрії, економіки й суспільства. Ті країни, 
міста, компанії тощо, які враховували ці мегатренди, досягли успіху. Так, реформи 1980-х років дозволили Китаю скористатись глобалізацією; Лондон скористався лібералізацією фінансових ринків, що зробило його світовим хабом; Індія та США скористались можливостями, що виникли через появу інтернету [8].

За прогнозами фахівців у найближчі п’ять років перспективи розвитку матимуть: ексабайтова економіка, у якій планується створити ринки обсягом понад 8 трлн. дол., економіка добробуту (понад 7 трлн. дол.), вуглецевонейтральна економіка (майже 2,3 трлн. дол.), циркулярна економіка (4,5 трлн. дол.), економіка вражень (принаймні 6,5 трлн. дол.) ma iн. [8], що повинні враховувати країни, які прагнуть сталого розвитку та національної безпеки.

Фахівці вважають, що формування нового світового порядку, заснованого на використанні технологій штучного інтелекту, відмові від використання вуглецевого палива, повсюдної цифровізації та ін. завершується [9]. Зазначене переформатування призведе до зростання потреби в акумуляторах і літієвих батареях для автівок і промисловості майже у три рази протягом п'яти років. До 2040 року потреба в літії збільшиться майже у 40 разів та у 25 разів - у графіті та ін. рідкоземельних матеріалах. США зможуть забезпечити принаймні десяту частину необхідних потужностей, Китай контролює приблизно 55\% їх видобутку i 85\% - очищення [9]. Україна належить до країн світу, які володіють мінеральними ресурсами. Так, запаси літію - одні 3 найбільших в Свропі. С, також, графіт, мідь, кобальт, нікель, титан, хром, тантал та ін. поклади рідкоземельних металів, вартість яких оцінюється у 7,5 трлн. дол. США [9]. У стратегічно привабливих для провідних економік світу видах діяльності Україна має потужний потенціал. Але партнерство України 3 провідними економіками світу у цих напрямках має передбачати не експорт ресурсів до різних держав, а готової продукції з великою доданою вартістю.

Зрозуміло, що для цього потрібні фахівці з відповідними компетентностями. Роботодавці світу, і Україна в цьому питанні не виняток, скаржаться, що не можуть знайти працівників із необхідними компетентностями, бо вони відсутні на ринку праці. Існуюча робоча сила із стандартними навичками неминуче потрапляє у пастку невідповідності їх компетентностей сьогоднішнім вимогам бізнесу, тобто у світі спостерігається негативна тенденція - наявність глибокої кваліфікаційної ями, яка є серйозним бар'єром для впровадження інновацій та економічного розвитку: втрати світового ВВП у 2017 р. становили принаймні 5 трлн. дол. США через зниження майже на 6\% продуктивності праці у країнах OECP [7, с. 8]; у 45\% роботодавців виникають труднощі 3 пошуком співробітників необхідної кваліфікації. Найближчим часом будуть затребувані зовсім нові спеціалісти, які не лише розбиратимуться у своїй галузі, але й матимуть крос-галузеву спеціалізацію - набір компетентностей, що дозволять знайти роботу на перехресті кількох галузей; майже 1,3 млрд. працівників відчули проблему невідповідності навичок запитам бізнесу; за останні 30 років у 
2-3 рази зросла вартість освіти [7, с. 23], а середня тривалість навчання за останні 50 років збільшилась у розвинених країнах у 1,9 рази, а в країнах, що розвиваються, у 3,6 рази і продовжує зростати [7, с.17].

У XXI столітті регулярно виникають новітні технології, на базі яких створюються нові види бізнесу, що формують попит на нові спеціальності, котрі чинна система освіти не може оперативно пропонувати ринку праці, бо перелік професій, які пропонують 3ВО, не відповідає потребам часу, а грунтується на їхньому розумінні поточної ситуації та наявних викладачах, відсутнє довгострокове прогнозування потреб ринку праці. В умовах невизначеності та непередбачуваності ситуацію підсилює той факт, що актуальний набір професій постійно оновлюється. В результаті, ринок праці та ринок освітніх послуг розбалансовані. У стратегії розвитку держави відсутні плани щодо підготовки фахівців за новими спеціальностями, які будуть затребувані у довгостроковій перспективі.

Внаслідок дисбалансу потреб бізнесу і можливостей ринку праці та працівників виникають численні виклики:

- недостатній рівень підготовки працівників до нових видів діяльності та набуття нових компетентностей. Існуюча система закладів вищої освіти не здатна ефективно адаптуватися до мінливого світу і не вчить людей готуватись до нових реалій;

- у більшості співробітників відсутня культура перманентного розвитку та перепідготовки впродовж життя. У сучасному світі технічні навички застарівають за 2-5 років. Нині щороку оновлюється майже 5\% теоретичних і $20 \%$ професійних знань [10]. За прогнозами від 75 до 375 млн. людей будуть змушені оволодівати новими навичками для того, щоб адаптуватися до цифровізації світу [11]. Тому зростатиме попит на офлайн-курси перепідготовки та підвищення кваліфікації, масові відкриті онлайн-курси, короткострокові тренінги, вебінари, стажування, менторство від фахівців певної галузі;

- низький рівень внутрішньої мотивації і почуття відповідальності за власний професійний розвиток у працівників. За оцінками експертів дитина, якій сьогодні виповнилось десять і більше років, змінюватиме роботу принаймні сім разів впродовж життя, і п'ять 3 цих видів діяльності виникнуть у майбутньому [7, c. 8]. Наразі для роботи цивілізованої людини найбільш актуальними фахівці вважають такі основні soft skills: командна робота і вміння вести перемовини, мультимовність, гнучкість розуму та емоційний інтелект, системне мислення, креативність і критичне мислення, самоорганізація і саморозвиток, володіння цифровими інструментами, розуміння правил і норм, відповідальність i лояльність тощо. Тому сучасний фахівець, крім професійних компетентностей, має опанувати універсальний набір soft skills для того, щоб бути успішним в умовах глобальної непередбачуваності та невизначеності. На жаль цей перелік змінюється 3 тією ж швидкістю, що й оточуючий світ, проте компетентності не прив'язані до певної області, а необхідні для досягнення успіху в самих різних 
професійних сферах;

- обмежений доступ до можливостей ринку праці. За оцінками експертів $41 \%$ пошукувачів знаходять роботу на онлайн-платформах i $14 \%$ через соцмережі. Проте не всі країни і не всі регіони всередині держави мають однаковий доступ до Інтернету [7, с. 29];

- локальні дисбаланси людського капіталу на ринку праці через поглиблення урбанізації та мобільність персоналу. Чисельність потенційних кандидатів, чиї навички і знання відповідають вимогам вакансії, при розширенні географії пошуку збільшується на 2-20\%. Наприклад, ситуація з Польщею, яка відкрила кордони і з радістю працевлаштовує заробітчан з України;

- не використаний потенціал окремих груп працездатного населення. Мова йде про категорії людських ресурсів, які через певні існуючі обмеження не працюють: це жінки, які виконують хатню роботу та доглядають за дітьми, особи похилого віку (у багатьох країнах спостерігається старіння населення i ïx кількість стрімко збільшується) і люди з інвалідністю;

- зміна цінностей і потреб працівників. Для представників покоління Z, яких щороку на ринок праці виходить все більше, важливими $є$ саморозвиток $\mathrm{i}$ баланс між роботою та особистим життям. Лише $36 \%$ представників Z-генерації розглядають просування по службових сходинках як основний пріоритет у роботі. Вони схильні частіше міняти не тільки роботодавців, але й сфери діяльності. Такі тренди наразі виникають і серед представників інших поколінь $[7$, c. 8$]$.

Між провідними економіками світу через збільшення чисельності старіючого населення точиться боротьба за інтелектуальні ресурси і робочу силу. Провідні країни Європи скасовують або знижують ціни на освіту, розробляють і реалізують державні програми залучення талантів, які генеруватимуть нові ідеї, організовуватимуть стартапи, створюватимуть проривні продукти у сфері IT та штучного інтелекту [9].

Аби не стати експортером талантів та робочої сили для розвинутих країн сучасні вітчизняні ЗВО мають долучитись до вирішення проблем кваліфікаційної ями і забезпечити необхідний розвиток людського капіталу.

Висококваліфіковані і мобільні кадри, як показує досвід останніх років, в економіці не з'являться самі по собі. Світ у XXI столітті формує нові запити щодо якості і різноманітності компетентностей працівників, але освітній системі потрібен час, щоб перейти від системи освіти, основи якої закладено в епоху Індустрії 2.0 (вимоги до робітника 3 боку масштабного індустріального виробництва: стандартизовані знання та навички, здатність дисципліновано виконувати типові дії протягом життя) до нових запитів, характерних Індустрії 4.0, яка передбачає масову персоналізацію освіти. Наразі потрібно адаптувати підходи у ЗВО під потреби кожної людини. На нашу думку цьому сприятимуть: масова персоналізація освіти шляхом формування індивідуальних освітніх траєкторій; тьюторинг; формування культури перманентного розвитку та освіти 
впродовж життя; розвиток дистанційної освіти, формування бренду ЗВО та викладачів в умовах цифровізації.

Розглянемо можливості реалізації напрямків розвитку людського капіталу на прикладі Херсонської державної морської академії (ХДМА).

У кожного викладача ХДМА на платформі Moodle є власні веб-сторінки, де розміщений необхідний контент. Платформу Moodle та ін. цифрові інструменти пропонуємо використати для побудови індивідуальних освітніх траєкторій (а також і для моніторингу їх опанування) для талановитих здобувачів вищої освіти 3 можливістю відвідувати певні курси в інших університетах, наприклад, дистанційно або офлайн за домовленістю з адміністрацією відповідних ЗВО. Така траєкторія полягає в тому, що набір дисциплін, їх зміст, формати і темп вивчення адаптуються під потреби, інтереси і можливості персоналізовано під конкретного здобувача. Зрозуміло, що здобувачі, які матимуть такий унікальний трек розвитку отримуватимуть особливі, більш глибокі знання та компетентності, а також матимуть можливість долучитись до наукових досліджень 3ВО, що водночас сприятиме зростанню обсягів наукових досліджень закладу та поповненню лав науковців.

Унікальний трек розвитку здобувача може вирішити проблему кваліфікаційної ями: замість однакової освіти пропонуючи курсанту цікавий саме йому шлях. Це не означає, що здобувач вивчатиме дисципліни виключно за власним бажанням, а сутність запропонованої індивідуалізації освітніх траєкторій полягає в тому, що ЗВО має забезпечити базову підготовку, а також надавати необхідну допомогу щодо вибору та вивченню дисциплін відповідно до персональних нахилів і вподобань. Безумовно, для кожного здобувача вищої освіти сформувати персоналізовану програму розвитку наразі немає сенсу, але для успішних курсантів аби стимулювати їхній саморозвиток за допомогою різних платформ здається можливим. Такий підхід мотивуватиме й інших курсантів до покращення результатів навчання.

Сьогодні викладач перестав бути єдиним джерелом знань. В інтернеті $\epsilon$ багато різноманітних онлайн-курсів, але самотужки важко розібратись, які з цієї безлічі $є$ ефективними. Має бути помічник, порадник, який підкаже в якому напрямку рухатись і своєчасно підтримає у разі необхідності та поділиться власним досвідом. Тут має допомогти тьютор, який мотивуватиме, надихатиме на отримання знань, досвіду і розвитку, заохочуватиме до досягнення певних цілей, допомагатиме здобувачам реалізувати власний потенціал та вибудувати свою освітню програму відповідно до майбутнього уявлення життя [12]. Виникає питання: хто може бути професійним тьютором i де його взяти? Сучасна концепція постулює, що викладач сьогодні грає багато ролей: модератора, розробника освітніх траєкторій, тьютора, фасілітатора, організатора проєктного навчання, координатора освітніх онлайн платформ, ментора стартапів, гейміфікатора, тренера із майнд-фітнесу [13]), одна 3 яких і є той самий тьютор.

Варто зазначити, що 85\% працівників у світі мають низьку або середню 
кваліфікацію, що не відповідає запитам економіки майбутнього [7, с. 11]. Розвитку людського капіталу сприятиме концепція самостійного навчання, так звана хьютагогіка - наука про самоосвіту. Її сутність полягає в тому, що доросла людина самостійно набуває компетентностей у гуртках, на курсах, лекціях, хакатонах, у спілкуванні 3 тими, хто може чогось навчити, за допомогою занурення в середовище, в якому виникне бажання дізнаватися нове. Тобто освіта будується навколо людини, яка навчається [14]. I в цьому випадку можуть брати участь викладачі 3ВО в якості агентів змін, створюючи креативний хаб, розробляючи різноманітні актуальні дистанційні курси для тих, хто бажає отримати певні знання, компетентності або навіть професії майбутнього, аби бути затребуваними на ринку праці в умовах глобалізації економіки.

У США існує одиниця виміру застарівання знань фахівця - період «напіврозпаду» компетентності - зниження їі вартості на 50\% через появу нової інформації. Цей показник свідчить, що за багатьма професіями цей період відбувається навіть швидше, ніж за 5 років [14].

Вирішення проблеми полягає в реалізації концепції освіти впродовж життя. Вона полягає в тому, що після закінчення ЗВО отримана освіта є фундаментом, який періодично потрібно доповнювати новими навчальними курсами, програмами, тренінгами та ін., що відповідатимуть запитам ринку праці та адаптуватимуть працівника до мінливих умов життя. Це передбачає, що випускник ЗВО має сформувати компетентності до навчання протягом усього професійного життя, розвинути навички комунікації, адаптивності, самовдосконалення, організаційної й групової ефективності та ін. [14].

Освіта впродовж життя у світі стає дедалі важливішою сферою освітніх послуг, якою мають скористатись ЗВО і долучитись до процесу формування культури постійного розвитку та освіти впродовж життя [15, с. 177-184]. Основними елементами такої культури є: наявність лідерів, чіткі та зрозумілі всім працівникам місія та цінності, стимулювання відповідних активних дій, спрямованих на досягнення поставлених цілей, прозорість комунікацій всередині організації, вшанування команд та особистостей, які приносять перемоги, створення умов для навчання та розвитку тощо.

Дистанційна освіта на основі інтернет-технологій має низку переваг, як довів досвід освітньої діяльності в умовах пандемії COVID-19: здобувачі можуть спілкуватися з викладачами та обмінюватися матеріалами у мережі, перебуваючи в різних країнах світу; розширює коло потенційних здобувачів; сприяє гармонійному поєднанню навчання та повсякденного життя; дозволяє одержати освіту 3 мінімальними фінансовими витратами за умови великого вибору спеціальностей; $є$ чинником підвищення якості людського капіталу; допомагає викладачеві бути координатором та керівником навчального процесу і приділяти кожному здобувачу рівноцінну увагу; здобувачі мають можливість доступу до освіти у зручний час [16]. Дистанційний підхід до навчання дозволить кожній людині навчатися протягом всього життя. 
Найважливішим чинником конкурентоспроможності і фінансової стійкості організації фахівці вважають іï бренд. Його базою є репутація, яка завдяки інвестиціям у власний бренд та відповідну організаційну культуру перетворюється на капітал. Так, вартість репутаційного капіталу у Apple становить $\$ 455$ млрд. або 62\% вартості корпорації, Microsoft - $\$ 442$ млрд. або 88\%, Facebook - \$344 млрд. або 84\%, Amazon - \$410 млрд. або 95\% [17, с.141]. Виникає потреба у формуванні такого важливого активу ЗВО як бренд, який привертатиме увагу і викликатиме довіру та зацікавленість у всіх, хто бажає здобувати якісну освіту саме у цьому закладі й оволодівати необхідними компетентностями.

Формуванню міцних конкурентних переваг, зростанню репутаційного капіталу ЗВО сприятиме створення цифрового золота закладу, що дозволить зробити прозорим та зручним процес освітньої діяльності, впровадити сильну корпоративну культуру, створити особистий бренд викладача. Викладачі надають освітні послуги здобувачам та науковий продукт своїм ЗВО та суспільству в цілому. Своєю роботою вони щодня формують «власний продукт», залучаючи необхідні ресурси та надаючи ефективні матеріали певній аудиторії [18].

Створення особистого бренду викладача сприятиме поширенню ідей, їх популяризації та монетизації, тобто у разі наявності цікавої, корисної думки можна виступати з лекціями, курсами (наприклад, про освіту впродовж життя; аналіз мегатрендів, їх вплив на діяльність людини/бізнес; надання послуг щодо ефективного оволодіння цифровими технологіями, фізичною культурою в контексті здорового способу життя, іноземними мовами, методів викладання та гейміфікації; формування стресостійкості в умовах перманентних змін, лідерських якостей та ін.) тренінгами, формуючи бренд ЗВО та привертаючи увагу до себе та закладу.

Завдяки платформі Moodle (у ХДМА), соціальним мережам, різноманітним застосункам професійний бренд викладача може стати ефективним інструментом налагодження комунікації із здобувачами, залученням нової аудиторії на власні авторські курси, поширення власних напрацювань та розробок (в т.ч. 3 метою підвищення рівня цитованості, які визначені ліцензійними умовами), обміну думками та досвідом між колегами, започаткування нового проекту, встановлення партнерства для наукової роботи або надання консультативних послуг бізнесу тощо. Створення особистого бренду є тривалим процесом, вимагає креативності, стратегічного мислення, але цей процес доступний кожному викладачу, який вже є або тільки прагне стати лідером думок та експертом у своїй галузі.

Висновки. Проаналізовано втрати бізнесу від наявної кваліфікаційної ями в світі. Визначено виклики, які виникають внаслідок дисбалансу потреб бізнесу і можливостей ринку праці та співробітників. Сьогодні кожна людина може навчатися самостійно. Тому ЗВО необхідно створити екосистему, в якій здобувач відправиться у вільне плавання, бо сучасна система освіти не повинна 
примушувати навчатись, а має мотивувати, надихати, допомагати, скеровувати дії у потрібному напрямі.

На основі проведеного аналізу з метою подолання кваліфікаційної ями та адаптації закладів вищої освіти під потреби кожної людини запропоновано: впроваджувати масову персоналізацію освіти шляхом формування індивідуальних освітніх траєкторій, тьюторинг, формувати культуру постійного розвитку та освіти впродовж життя, розвивати дистанційну освіту, створювати бренд закладу вищої освіти та особистий бренд викладача.

\section{Лimepamypa:}

1. Чайкіна А.О. Індустрія 4.0: особливості цифрової трансформації України. Вчені записки ТНУ ім. В.І. Вернадського. Серія: Економіка і управління. 2021. Т.32 (71). №3. С. $24-31$.

2. Освіта протягом життя як чинник людського розвитку. Аналітична записка. Національний інститут стратегічних досліджень. URL: https://niss.gov.ua/doslidzhennya/ gumanitarniyrozvitok/osvita-protyagom-zhittya-yak-chinniklyudskogo-rozvitku (дата звернення 10.09.2021).

3. Shultz T. Investment in Human Capital. Human Capital in the International Encyclopedia of the Social Sciences. N.Y., London, 1971. Vol. 6. P. 26-28.

4. Becker G.S., Human Capital and the Personal Distribution of income. An Analytical Approach. Ann-Arbor. 1967. 268 p.

5. Грішнова О.А. Людський капітал: формування в системі освіти і професійної підготовки. Київ: Т-во «Знання», КОО, 2001. С. 16-17.

6. Захарова О. Розвиток теорії інвестування в людський капітал. Україна: аспекти праиі. 2012. №3. C. 45-52.

7. Массовая уникальность. Глобальный вызов в борьбе за таланты. URL: https://webassets.bcg.com/f9/24/5f3a82564d6fa0d27a6d767ae0f6/rus-bcg-mas-uniq-tcm27-

228998.pdf?fbclid=IwAR3pBtUk9GUmOopw7c4j89B2U2bVTe_7GLf_JgabG2BoxU8VMFNaNyc-Z4Q (дата звернення 10.09.2021).

8. Шість економік майбутнього: де в ООН побачили ринки на $\$ 30$ трлн. Mind/ URL: https://mind.ua/publications/20214334-shist-ekonomik-majbutnogo-de-v-oon-pobachili -rinki-na-30-trln (дата звернення 12.09.2021).

9. Корсунский С. Точка бифуркации: как нам обустроить Украину. URL: https://zn.ua/international/tochka-bifurkatsii-kak-nam-obustroit-ukrainu.html (дата звернення 12.09.2021).

10. Освіта протягом життя: світовий досвід і українська практика. Аналітична записка. Національний інститут стратегічних досліджень. URL: https://niss.gov.ua/doslidzhennya/gumanitarniyrozvitok/osvita-protyagom-zhittya-svitoviy-dosvid-i-ukrainska-praktika (дата звернення 12.09.2021).

11. Професії майбутнього: де отримувати знання? Проєкm 2030talks. URL: https://2030talks.blog/future-jobs (дата звернення 12.09.2021).

12. Куликова Е. Тьюторинг - не для всех. Но должен быть доступен каждому. Портал Нова освima. URL: https://osvitanova.com.ua/posts/730-tiutorynh-ne-dlia-vsekh-no-dolzhen-byt-dostupenkazhdomu (дата звернення 12.09.2021).

13. Балацанова О. Професії майбутнього: які спеціалісти будуть затребувані післязавтра Українська правда життя URL: https://life.pravda.com.ua/ columns/2019/02/19/235691 (дата звернення 12.09.2021).

14. Ращупкина Е. Как современные подходы в образовании ставят студента в центр процесса обучения. Онлайн-университет Skillbox: веб-сайт. URL: https://skillbox.ru/media/education/kaksovremennye-podkhody-v-obrazovanii-stavyat-studenta-v-tsentr-protsessa-obucheniya (дата звернення 12.09.2021).

15. Стовба Т.А. Формування та розвиток інноваційної культури морського порту. "MODERNÍ ASPEKTY VĚDY” («Сучасні аспекти науки») : X том міжнародної колективної монографії / В.П. Хомутенко, Д.В. Мотигін, Т.A. Стовба та ін. Czесh Republic, 2021. C. 170-186. 
16. Водорєзова C.P. Перспективи розвитку дистанційної освіти в Україні. URL: https://ndipzir.org.ua/wp-content/uploads/2020/23.01.2020/Tezy_23_01_2020-23.pdf (дата звернення 12.09.2021).

17. Стовба Т.А., Панченко І.М. Трансформація викладання у морських ЗВО в умовах цифровізації: виклики та можливості. Перспективи та інноващії науки. 2021. №2 (2). С. 131-143.

18. Чи потрібен викладачу професійний бренд? Вище: веб-сайт. URL: http://gohigher.org/chi_potrben_vikladachu_profesyniy_brend (дата звернення 12.09.2021).

\section{References:}

1. Chaykina, A.O. (2021). Industriya 4.0: osoblyvosti tsyfrovoyi transformatsiyi Ukrayiny. [Industry 4.0: features of digital transformation of Ukraine]. Vcheni zapysky TNU im. V.I. Vernads'koho. Seriya: Ekonomika i upravlinnya - Scientific notes of TNU. VI Vernadsky. Series: Economics and Management, 32 (71), Vol. 3, 24-31 [in Ukrainian].

2. Osvita protyahom zhyttya yak chynnyk lyuds'koho rozvytku. Analitychna zapyska. Natsional'nyy instytut stratehichnykh doslidzhen'. [Lifelong learning as a factor of human development. Analytical note. National Institute for Strategic Studies]. (n.d.). niss.gov.ua. Retrieved from https://niss.gov.ua/doslidzhennya/ gumanitarniy-rozvitok/osvita-protyagom-zhittya-yak-chinnik-lyudskogo-rozvitku [in Ukrainian].

3. Shultz, T. (1971). Investment in Human Capital. Human Capital in the International Encyclopedia of the Social Sciences, 6, 26-28 [in English].

4. Becker, G.S. (1967). Human Capital and the Personal Distribution of income. An Analytical Approach. Ann-Arbor [in English].

5. Hrishnova, O.A. (2001). Lyuds'kyy kapital: formuvannya v systemi osvity i profesiynoyi pidhotovky [Human capital: formation in the system of education and training]. Kyyiv: T-vo «Znannya», KOO [in Ukrainian].

6. Zakharova, O. (2012). Rozvytok teoriyi investuvannya v lyuds'kyy capital [Development of the theory of investing in human capital]. Ukrayina: aspekty pratsi - Ukraine: aspects of work, 3, 45-52 [in Ukrainian].

7. Massovaya unikal'nost'. Global'nyy vyzov v bor'be za talanty [Mass uniqueness. A global challenge in the struggle for talent]. (n.d.). web-assets.bcg.com. Retrieved from https://webassets.bcg.com/f9/24/5f3a82564d6fa0d27a6d767ae0f6/rus-bcg-mas-uniq-tcm27-228998.pdf?fbclid=IwAR3pBtUk9G UmOopw7c4j89B2U2bVTe_7GLf_JgabG2BoxU8VMFNaNyc-Z4Q [in Russian].

8. Shist' ekonomik maybutn'oho: de v OON pobachyly rynky na $\$ 30 \operatorname{trln}$ [Six economies of the future: where the UN saw markets for $\$ 30$ trillion]. (n.d.). mind.ua. Retrieved from https://mind.ua/publications/20214334-shistekonomik-majbutnogo-de-v-oon-pobachili-rinki-na-30-trln [in Ukrainian].

9. Korsunskiy S. Tochka bifurkatsii: kak nam obustroit' Ukrainu [Bifurcation point: how we can equip Ukraine]. (n.d.). zn.ua. Retrieved from https:// /international/tochka-bifurkatsii-kak-nam-obustroit-ukrainu.html [in Russian].

10. Osvita protyahom zhyttya: svitovyy dosvid i ukrayins'ka praktyka. Analitychna zapyska. Natsional'nyy instytut stratehichnykh doslidzhen' [Lifelong learning: world experience and Ukrainian practice. Analytical note. National Institute for Strategic Studies]. (n.d.). niss.gov.ua. Retrieved from https://niss.gov.ua/doslidzhennya/gumanitarniy-rozvitok/osvita-protyagom-zhittya-svitoviy-dosvid-i-ukrainskapraktika [in Ukrainian].

11. Profesiyi maybutn'oho: de otrymuvaty znannya? Proyekt 2030talks [Professions of the future: where to get knowledge? Project 2030talks]. (n.d.). 2030talks.blog. Retrieved from https://2030talks.blog/future-jobs [in Ukrainian].

12. Kulikova, Ye. T'yutoring - ne dlya vsekh. No dolzhen byt' dostupen kazhdomu [Tutoring is not for everyone. But it should be available to everyone]. (n.d.). osvitanova.com.ua. Retrieved from https://osvitanova.com.ua/posts/730-tiutorynh-ne-dlia-vsekh-no-dolzhen-byt-dostupen-kazhdomu [in Russian].

13. Balatsanova, O. Profesiyi maybutn'oho: yaki spetsialisty budut' zatrebuvani pislyazavtra [Professions of the future: what specialists will be in demand the day after tomorrow]. (n.d.). life.pravda.com.ua. Retrieved from https://life.pravda.com.ua/ columns/2019/02/19/235691 [in Ukrainian].

14. Rashchupkina, Ye. Kak sovremennyye podkhody $\mathrm{v}$ obrazovanii stavyat studenta $\mathrm{v}$ tsentr protsessa obucheniya [How modern approaches in education put the student at the center of the learning process]. (n.d.). skillbox.ru. Retrieved from https://skillbox.ru/media/education/kak-sovremennye-podkhody-v-obrazovaniistavyat-studenta-v-tsentr-protsessa-obucheniya [in Russian]. 
15. Khomutenko, V.P., Motyhin, D.V., Stovba, T.A. at al. (2021). Formuvannya ta rozvytok innovatsiynoyi kul'tury mors'koho portu [Formation and development of innovative seaport culture]. "MODERNÍ ASPEKTY VĚDY” («Suchasni aspekty nauky»): X tom mizhnarodnoyi kolektyvnoyi monohrafiyi. Czech Republic, 2021 [in Ukrainian].

16. Vodoryezova, S.R. Perspektyvy rozvytku dystantsiynoyi osvity $\mathrm{v}$ Ukrayini [Prospects for the development of distance education in Ukraine]. (n.d.). ndipzir.org.ua. Retrieved from https://ndipzir.org.ua/wpcontent/uploads/2020/23.01.2020/Tezy_23_01_2020 -23.pdf [in Ukrainian].

17. Stovba, T.A., \& Panchenko, I.M. (2021) Transformatsiya vykladannya u mors'kykh ZVO v umovakh tsyfrovizatsiyi: vyklyky ta mozhlyvosti [Transformation of teaching in maritime free economic zones in the conditions of digitalization: challenges and opportunities]. Perspektyvy ta innovatsiyi nauky - Prospects and innovations of science, 2, 131-143 [in Ukrainian].

18. Chy potriben vykladachu profesiynyy brend? [Does a teacher need a professional brand?]. (n.d.). gohigher.org. Retrieved from http://gohigher.org/chi_potrben_vikladachu_profesyniy_brend [in Ukrainian]. 